\title{
EXAMINING INFLUENCED FACTORS OF THE PREPARATION PHASE ON TOTAL CONSTRUCTION TIME DELAY OF BUILD- OPERATE-TRANSFER TRANSPORT PROJECTS IN VIETNAM
}

\author{
Nguyen Hoang-Tung ${ }^{1 *}$, Pham Diem-Hang ${ }^{1}$
}

${ }^{1}$ Faculty of Construction Management, University of Transport and Communications, No. 3 Cau Giay Street, Hanoi, Vietnam.

\author{
ARTICLE INFO \\ TYPE: Research Article \\ Received: $24 / 7 / 2019$ \\ Revised: $25 / 8 / 2019$ \\ Accepted: 16/9/2019 \\ Published online: 15/11/2019 \\ https://doi.org/10.25073/tcsj.70.3.28 \\ * Corresponding author \\ Email: hoangtung@utc.edu.vn; Tel: 0936038389
}

\begin{abstract}
The involvement of private investors in public works has been widely-known under the scheme of Public-Private Partnerships (PPP) world-wide. Although being started in early years of the twenty-one century, the PPP scheme in Vietnam is still waiting for its booming period due to an incomprehensive regulation system. As of an approval of some important PPP decrees, the period of 2010-2018 is considered as a remarked period for the PPP development in Vietnam, especially in transport sector. Using the neural network approach, this study contributes to the literature by providing an insight of 48 build-operatetransfer (BOT) transport projects completed in the period. Findings of this study are meaningful to the field because they highlight several influenced factors of the project preparation phase those affect total completed construction time of the investigated projects.
\end{abstract}

Keywords: Public-Private Partnerships, Build Operate Transfer, Transport, Vietnam, Project Delay.

(C) 2019 University of Transport and Communications

\section{INTRODUCTION}

Public-Private Partnerships (PPP) is known as an essential alternative approach for developing infrastructure of a country due to its role in pushing up economic values [1] or 
Transport and Communications Science Journal, Vol. 70, Issue 3 (09/2019), 201-213

fostering the sustainability of the sector [2].

Motivated by financial benefits of the PPP scheme, researchers firstly approach the PPP on a viewpoint of an actual project [3] that is to focus on cost, concession, equity and contract analyses [4]. Such analyses are then upgraded into complicated financial models for various research objectives [5]. Financial aspects are also considered in numerous studies on the partnership between public and private sectors [6]. In addition, risk and success factors are of researchers' interests, in a particular of risk evaluation and allocation [7,8]. Moreover, a large number of studies have been conducted on management viewpoints, for example, procurement management [9], contract management [10] and performance management [11]. Of the governmental viewpoint, several topics have been shaped including modelling governance [12], implementing governance [13] and regulations [14].

In the context of developing countries, despite a common sense that the PPP scheme will improve project efficiencies and attract capital investments of private investors, numerous shortcomings have been identified. A study of Agarchand and Laishram [2] showed an unsatisfactory performance of PPP projects in India which is mainly due to procurement issues. Another research effort of Babatunde and others [15] has pointed out ten group factors considered as barriers to PPP projects in Nigeria context. Among those, a problem caused by delays has been revealed including receiving payments [16], negotiations, lengthy bureaucratic procedures or political debates $[17,18]$.

Of Vietnam context, a large portion of PPP projects were found inefficient and/or not able to achieve their investment objectives [19]. The main reason for such inefficiency is probably due to a weak legal framework [20]. Up to our latest awareness, it is surprisingly noted that most of studies of Vietnam context is to focus on legal framework issues, for example, identifying factors for a successful PPP implementation [21], thus lacking of a systematic view based on practical evidences of numerous project implementations.

In particular, as of reports of the government inspectorate of Vietnam on the implementation of various BOT transport projects, it is noted that a large portion of the projects is behind their schedules [22, 23]. Numerous causes of the delay have been reported, for example, settlement issues, funding issues, etc. These causes are of both the preparation phase and the implementation phase. While regulatory efforts of Vietnamese authorities are urgently made to solve the problem [24], it is obvious that such efforts take time to be effective. As such, it is needed to look for supporting solutions to deal with the problem of project construction delays.

In a notion that risk allocation is one of key barriers preventing private sector in participating in PPP transport projects in Vietnam [25], and construction delays are probably among critical causes increasing the negative exposure of project risks, we argue that project delays should be considered a kind of risk and this risk should be aware of at a very first stage of a project implementation. In other words, factors that allow us to recognize the problem of 
construction delays should be identified as soon as possible at the preparation phase. It is however that there are no studies in Vietnam context considering such important issue.

Motivated by the above-mentioned shortcomings, this study aims to investigate influenced factors of the preparation phase those affect total construction time of buildoperate-transfer (BOT) transport projects completed during a period of 2010 to 2018. Several related issues are also revealed to provide a better understanding of the BOT projects in transport sector of Vietnam during the investigation period.

To serve the purpose of this study, various factors of the preparation phase those are potential in affecting total construction time are firstly theoretically identified. These factors and total construction time delay are then empirically obtained by a questionnaire interview with project-related parties. Based on the collected data, the relationship between the investigated factors and total construction time delay is determined using a data mining technique called multilayer perceptron (MLP). Results of the MLP model allow us to determine the role of each of the factors in affecting total construction time delay.

\section{MODELLING APPROACH}

\section{The investigated factors}

Being the first study exploring influenced factors of the preparation phase on total construction time delay, various factors have been considered including experiences of the project management unit, experiences of investors, status of cost modification, number of investors, site dispersion, new construction involvement and number of provinces.

As suggested by a critical role of experiences in performance of PPP projects [26], experiences of investors and the project management unit have been investigated. The project management unit acts as the one to coordinate all stakeholders of a project, as such its experiences may take a critical role in deciding the smoothness of project implementation, thus contributing to the project total construction time. Investors are known to have a strong influence on most of the project activities, their experiences can therefore be considered as an important factor in affecting project construction time.

In awareness of numerous issues related to legal framework, norms, administrative procedures and site clearance of PPP projects [24], numerous factors are supposed to affect project total construction time. Cost modification before the start of construction work may affect construction contractors' implementation strategies, thus indirectly affect the total construction time. Because of different administrative procedures and issues of benefit confliction, number of investors and provinces involved in a project can also be seen as factors those contribute to a longer "waiting time" of a project implementation. Finally, noted as a major problem of project delay in the practice of Vietnam [23], the problem of site clearance is investigated through two factors of the preparation phase including site dispersion and new construction involvement. While numerous site locations may increase negotiation 
Transport and Communications Science Journal, Vol. 70, Issue 3 (09/2019), 201-213

time with local citizen, the involvement of new construction work obviously requires time for site clearance that has a high risk of project delay.

\section{Multilayer perceptron}

The MLP has been widely used in various disciplines. Of transport studies, the technique is widely employed in traffic forecasting [27] and service performance [28]. The outstanding advantage of MLP is to strongly detect complicated patterns and/or trends between input and output data. Advantages and disadvantages of MLP can be found in several studies [29].

The multilayer perceptron has a network of nodes. These nodes act as processing elements. The elements are arranged in three or more layers typically including input layer, hidden layers and output layer. This is illustrated in Figure 1.

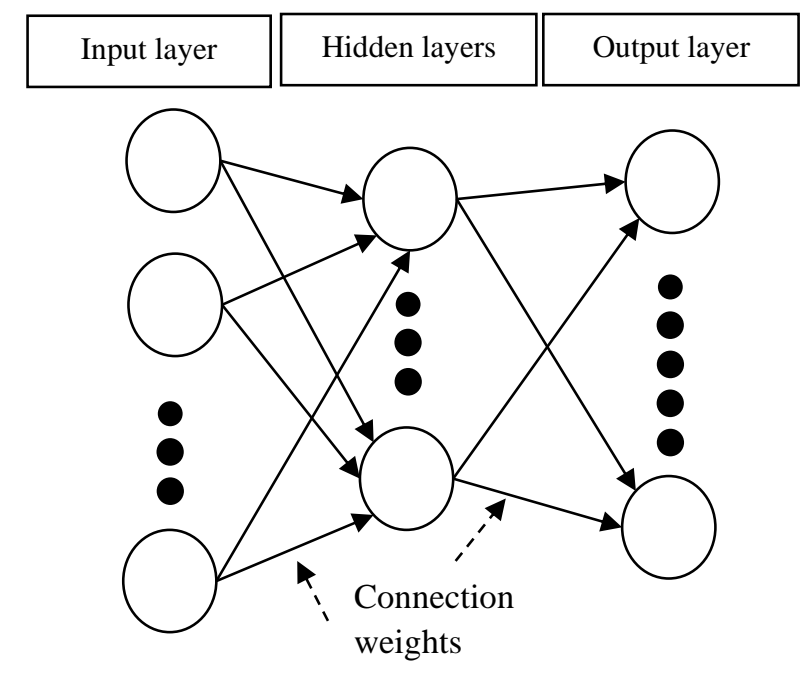

Figure 1. Components of a multilayer perceptron network.

In principle, when data is available at input layers, calculations will be performed in successive layers until each of output nodes has its value. Such values show the class appropriateness of the input data. A node is considered as an artificial neuron which produces the weighted sum of inputs under consideration of bias. The sum is then processed under an activation function. This process is described as follows:

$$
\omega_{j}=\sum_{i=1}^{m} \tau_{j i} x_{i}+\varepsilon_{j} \text { and } \gamma_{j}=f_{j}\left(\omega_{j}\right)
$$

Where $\omega_{j}$ is a linear combination of inputs $x_{i} ; \varepsilon_{j}$ is the bias; $\tau_{j i}$ is connection weights and $\gamma_{j i}$ is the output of a node.

An activation functions acts a link to connect the weighted sums in a layer to unit values in the next layer. In this study, the activation function for hidden layers is hyperbolic tangent and the activation function for output layer is softmax. The functions have following forms:

Hyperbolic tangent: $\quad f(\omega)=\tanh (\omega)=\frac{e^{\omega}-e^{-\omega}}{e^{\omega}+e^{-\omega}}$ 
Softmax:

$$
f\left(\omega_{k}\right)=\frac{\exp \left(\omega_{k}\right)}{\sum_{j} \exp \left(\omega_{j}\right)}
$$

Where $\mathrm{k}, \mathrm{j}$ are indicators of nodes.

The hyperbolic tangent uses real-valued arguments and transforms them to the range $(-1$, 1), whilst softmax uses a vector of real-valued arguments to produce a vector whose elements are within the range $(0,1)$ and sum to 1 .

Of training mechanism, Batch training strategy is employed. Details of the Batch training can be found at Jang and others work [30]. The training need a pass of all training data before updating the synaptic weights. In other words, it processes all information of the training dataset. The training is preferred by researchers due to its direct approach in minimizing the total error.

\section{DATA}

\section{Data collection}

A data survey has been implemented in Fall 2018. Interviewees are from the Ministry of Transport and project-related Provincial People Committees. The same questionnaire set has been repeatedly used for different interviewees. There are no specific requirements towards the number of the interviewees. The survey is stopped when all needed information of the investigated projects is obtained. Interviewees were asked to fill in a two-dimension table in which each row contains information of a project and each column indicates a tier of information. After two weeks of the survey implementation, data collected is screened to make sure similar answers are obtained for the same question. This guarantees the reliability of the survey data.

A total of 51 completed BOT transport projects have been investigated through out the country. After data screening process, three projects are excluded due to contradict data sources, thus data of 48 projects is used for analyses. Various factors of the preparation phase of a project have been investigated, in which total construction time delay is calculated by subtracting actual total construction time to planned total construction time. List of investigated BOT projects and factors are presented in Table 1a and $1 \mathrm{~b}$.

Table 1a. List of investigated BOT projects.

\begin{tabular}{clcl}
\hline 1 & $\begin{array}{l}\text { Bypass road of Vinh city and expansion of NH No.1A } \\
\text { section Ben Thuy - Hatinh City }\end{array}$ & 25 & $\begin{array}{l}\text { Construction of Phuoc Tuong - Phu Gia Tunnel, NH No.1A in } \\
\text { Thua Thien Hue province }\end{array}$ \\
\hline 2 & $\begin{array}{l}\text { Expansion of NH No.1 section Km672+600 - } \\
\text { Km704+900 in Quang Binh province }\end{array}$ & 26 & $\begin{array}{l}\text { Expansion of NH No.1 section Km987 - Km1027 in Quang Nam } \\
\text { province }\end{array}$ \\
\hline 3 & $\begin{array}{l}\text { Expansion of NH No.1 section Km947 - Km987 in } \\
\text { Quang Nam province }\end{array}$ & $\begin{array}{l}\text { Construction of Co Chien bridge NH No.60 in Ben Tre and Tra } \\
\text { Vinh provinces }\end{array}$ \\
\hline 4 & $\begin{array}{l}\text { Expansion of NH No.1 section Km1212+400-Km1265 } \\
\text { in Binh Dinh and Phu Yen provinces }\end{array}$ & 28 & $\begin{array}{l}\text { Bypass of NH No.1 section Phu Ly City and upgrading NH No.1 } \\
\text { section Km215+775-Km235+885 in Ha Nam }\end{array}$ \\
\hline 5 & $\begin{array}{l}\text { Expansion of NH No.1 section Km741+170- } \\
\text { Km756+705 in Quang Tri province }\end{array}$ & $\begin{array}{l}\text { Expansion of NH No.1 section Northern side of Bac Lieu City and } \\
\text { Correction of some flooded sections of NH No.1 }\end{array}$ \\
\hline $6 \quad \begin{array}{l}\text { Upgrading of NH No.18 section Uong Bi City - Ha } \\
\text { Long City }\end{array}$ & 30 & $\begin{array}{l}\text { Upgrading of Ho Chi Minh road (NH No.14) section } \\
\text { Km1793+600 dến Km1824+00 in Dak Nong province }\end{array}$ \\
\hline
\end{tabular}


Transport and Communications Science Journal, Vol. 70, Issue 3 (09/2019), 201-213

\begin{tabular}{|c|c|c|c|}
\hline 7 & Bypass road of NH No.1 Section Bien Hoa City & 31 & Upgrading NH No.91 section Km14+000 - Km50+889 \\
\hline 8 & Upgrading of NH No.1 Section Phan Thiet - Dong Nai & 32 & Expansion of NH No.1 with 4 sections in Ninh Thuan province \\
\hline 9 & $\begin{array}{l}\text { Expansion of } \mathrm{NH} \text { No.1 section Km368+400 } \div \\
\text { Km } 402+330 \text { in Thanh Hoa and Nghe An provinces }\end{array}$ & 33 & $\begin{array}{l}\text { Upgrading of Ho Chi Minh road section from NH No.2 to Huong } \\
\text { Non and Expansion of NH No. } 32 \text { section from Co Tiet to Trung } \\
\text { Ha Bridge }\end{array}$ \\
\hline 10 & $\begin{array}{l}\text { Upgrading of Ho Chi Minh road (NH No.14) section } \\
\text { No. } 38 \text { bridge - Dong Xoai village in Binh Phuoc } \\
\text { province }\end{array}$ & 34 & $\begin{array}{l}\text { Expansion of NH No.1 section Km2118+600 - Km2127+320,75 } \\
\text { and Bypass construction for NH No.1 section Soc Trang City }\end{array}$ \\
\hline 11 & $\begin{array}{l}\text { Expansion of NH No.1 section Km597+549-Km605 } \\
\text { and Km617-Km641 in Quang Binh province }\end{array}$ & 35 & $\begin{array}{l}\text { Rehabilitation of } \mathrm{NH} \text { No.20 section } \mathrm{Km} 123+105,17 \text { - } \\
\text { Km268+000 in Lam Dong province }\end{array}$ \\
\hline 12 & $\begin{array}{l}\text { Upgrading of Ho Chi Minh road (NH No.14) section } \\
\text { Pleiku (Km1610) - No. } 110 \text { bridge }(\mathrm{Km} 1667+570) \text { in } \\
\text { Gia Lai province }\end{array}$ & 36 & Upgrading of Phap Van- Cau Gie road \\
\hline 13 & $\begin{array}{l}\text { Upgrading of Ho Chi Minh road (NH No.14) section } \\
\text { Km1738+148 - Km1763+610 in Dak Lak }\end{array}$ & 37 & $\begin{array}{l}\text { Construction of Deo Ca tunnel NH No.1 in Phu Yen and Khanh } \\
\text { Hoa province }\end{array}$ \\
\hline 14 & $\begin{array}{l}\text { Expansion of NH No.1 section Km791A+500- } \\
\text { Km848+875 in Thua Thien Hue province }\end{array}$ & 38 & $\begin{array}{l}\text { Bypass of NH No. } 1 \text { and road surface improvement section Cai } \\
\text { Lay village of Tien Giang province }\end{array}$ \\
\hline 15 & $\begin{array}{l}\text { Construction of My Loi bridge at Km34+826 (NH } \\
\text { No.50) in Long An and Tien Giang provinces }\end{array}$ & 39 & $\begin{array}{l}\text { Construction of Bypass section Ninh Hoa Village and Upgrading } \\
\text { NH No.26 section Km3+411- Km11+504 and section Km91+383 } \\
\text { - Km } 98+800\end{array}$ \\
\hline 16 & $\begin{array}{l}\text { Expansion of NH No.1 section Km1642 - Km1692 in } \\
\text { Binh Thuan province }\end{array}$ & 40 & $\begin{array}{l}\text { Construction of NH No.38 section from Yen Lenh bridge to Vuc } \\
\text { Vong intersection }\end{array}$ \\
\hline 17 & $\begin{array}{l}\text { Expansion of NH No.1 section Km1374+525 - } \\
\text { Km1392 and section Km1405 - Km1425+500 }\end{array}$ & 41 & $\begin{array}{l}\text { Upgrading NH No.10 section from La Uyen bridge to Tan De } \\
\text { bridge and Bypass of Dong Hung village }\end{array}$ \\
\hline 18 & $\begin{array}{l}\text { Expansion of NH No.1 section Km1488-Km1525 in } \\
\text { Khanh Hoa province }\end{array}$ & 42 & $\begin{array}{l}\text { Construction of Hoa Lac - Hoa Binh road and Upgrading NH } \\
\text { No.6 section Xuan Mai - Hoa Binh }\end{array}$ \\
\hline 19 & $\begin{array}{l}\text { Construction of a new Viet Tri bridge passing Lo river } \\
\text { NH No. } 2\end{array}$ & 43 & $\begin{array}{l}\text { Construction of Thai Nguyen -Cho Moi road and Upgrading NH } \\
\text { No.3 section } \mathrm{Km} 75-\mathrm{Km} 100\end{array}$ \\
\hline 20 & Expansion of NH No.1 section Can Tho - Phung Hiep & 44 & $\begin{array}{l}\text { Construction of Thai Ha bridge passing Hong river connecting } \\
\text { Thai Binh and Ha Nam provinces to Cau Gie expressway, Phase } 1\end{array}$ \\
\hline 21 & Expansion of NH No.1 section Hanoi - Bac Giang & 45 & $\begin{array}{l}\text { Upgrading NH No.10 section Quan Toan bridge to Nghin bridge } \\
\text { in Hai Phong City. }\end{array}$ \\
\hline 22 & $\begin{array}{l}\text { Expansion of NH No.1 section Km1125-Km1153 in } \\
\text { Binh Dinh province }\end{array}$ & 46 & $\begin{array}{l}\text { Construction of Viet Tri - Ba Vi bridge connecting NH No.32 to } \\
\text { NH No.32C in Hanoi City and Phu Tho province }\end{array}$ \\
\hline 23 & $\begin{array}{l}\text { Upgrading of NH No.19 section } \mathrm{Km} 17+027 \text { - } \\
\text { Km50+00 and section } \mathrm{Km} 108+00-\mathrm{Km} 131+300\end{array}$ & 47 & $\begin{array}{l}\text { Upgrading NH No.38 section connecting NH No.1 to NH No.5 in } \\
\text { Bac Ninh and Hai Duong provinces }\end{array}$ \\
\hline 24 & $\begin{array}{l}\text { Expansion of NH No.1 section Km1063+877 - } \\
\text { Km1092+577 in Quang Ngai province }\end{array}$ & 48 & Upgrading NH No.18 section Bac Ninh - Uong Bi \\
\hline
\end{tabular}

Table 1b. List of investigated factors.

\begin{tabular}{clcclc}
\hline No. & Name of Factor & Unit & No. & Name of Factor & Unit \\
\hline 1 & No. of provinces & - & 9 & Planned construction time & Month \\
\hline 2 & $\begin{array}{l}\text { New construction } \\
\text { involvement }\end{array}$ & Yes/No & 10 & Actual construction time in months & Month \\
\hline 3 & $\begin{array}{l}\text { Site dispersion } \\
\text { No. of site } \\
\text { location }\end{array}$ & 11 & Total planned cost (PC) & Mil. USD \\
\hline 4 & GDP Per Capital & USD & 12 & PC by Government & Mil. USD \\
\hline 5 & $\begin{array}{l}\text { Experiences } \\
\text { management unit }\end{array}$ & Year & 13 & PC by Investor & Mil. USD \\
\hline 6 & $\begin{array}{l}\text { Experiences } \\
\text { investor }\end{array}$ & Year & 14 & PC by Loan & Mil. USD \\
\hline 7 & $\begin{array}{l}\text { Project length } \\
8\end{array}$ & Km & 15 & Cost modified status & Yes/No \\
\hline
\end{tabular}


It should be noted that although various cost-related factors are collected, not all of them are potential influenced factors of total construction time delay. In particular, total planned cost and its dividends including PC by government, PC by Investor and PC by Loan are mainly to provide a rough picture of project scopes as well as the involvement of private sectors in projects. These factors are mainly used for descriptive and statistical group analyses to provide a general understanding of the investigated projects.

\section{ANALYSES}

\section{Descriptive Analyses}

Characteristics of investigated factors are summarized in Table 2. As can be seen from the table, in average, BOT projects are involved in more than a province with nearly a haft of them having new construction package as well as a separation of site locations. The average GDP per capital of the investigated provinces are more than 2000 USD indicating a medium income of the citizen. Investors and management units are all experienced in doing their jobs, in which management units have an average of more than 10 years in project management and investors averagely have more than 20 years doing investment work. With an approximate of $35 \mathrm{~km}$ long per project, it is observed that each project has nearly two investors and approximately 111 million USD of the total investment cost. In addition, the cost modification is not rare among the investigated projects. Finally, in average, the projects are 4 months behind their schedules, making a note on the project delay situation of the BOT projects.

Table 2. Investigated factors

\begin{tabular}{lr|r|r|r|r}
\hline & N & Minimum & Maximum & Mean & Std. Deviation \\
\hline No. of provinces & 48 & 1.00 & 2.00 & 1.27 & .45 \\
\hline New construction involvement & 48 & .00 & 1.00 & .40 & .49 \\
\hline Site dispersion & 48 & 1.00 & 2.00 & 1.33 & .48 \\
\hline GDP Per Capital & 48 & 1030.00 & 4196.00 & 2099.36 & 803.54 \\
\hline Experiences of management unit & 48 & 6.00 & 19.00 & 10.85 & 2.95 \\
\hline Experiences of investor & 48 & 2.00 & 49.00 & 20.79 & 14.58 \\
\hline Project length & 48 & 2.00 & 145.00 & 35.85 & 27.84 \\
\hline No. of investors & 47 & 1.00 & 4.00 & 1.79 & .88 \\
\hline Planned construction time & 47 & 9.00 & 95.00 & 27.15 & 14.00 \\
\hline Actual construction time & 47 & 13.00 & 86.00 & 31.04 & 13.95 \\
\hline Total planned cost (PC) & 48 & 19.73 & 887.48 & 111.23 & 125.24 \\
\hline PC by Government & 48 & .00 & 236.77 & 7.91 & 35.32 \\
\hline PC by Investor & 48 & 2.96 & 119.68 & 15.67 & 16.89 \\
\hline PC by Loan & 48 & 16.77 & 531.02 & 87.66 & 79.08 \\
\hline Cost modified status & 48 & .00 & 1.00 & .33 & .48 \\
\hline Total construction time delay & 47 & -22.00 & 61.00 & 3.89 & 13.46 \\
\hline
\end{tabular}


Transport and Communications Science Journal, Vol. 70, Issue 3 (09/2019), 201-213

In addition, Pearson correlation analyses showed that there are significant associations between experiences of investors and planned construction time (coefficient $=-.294$; Sig.2tailed $=.045$ ); GDP per capital and actual construction time (coefficient $=.416$; Sig.2tailed $=.004$ ); and GPD per capital and project length (coefficient $=.302$; Sig.2tailed $=$ .037). A significant correlation between total construction time delay and planned construction time is also observed (coefficient $=-.484$; Sig.2tailed $=.001$ ). It should be noted that although there are insignificant correlations, the relationship trends between investigated factors and total construction time delay are reasonable. In particular, delay increases when there is an involvement of new construction or there is a greater experience of management units and/or investors as well as a greater number of investors. And delay decreases when there is a lower number of involved provinces and/or site locations.

\section{Statistical group analyses}

With an aim to explore some investment trends, group comparison analyses have been conducted. Results of independent sample T-test analyses are presented in Table 3.

Table 3 showed that there is a significant difference in the means of planned investment cost by loan between two groups of GDP. Project locations having GDP per capital higher than 2000 USD will attract a higher loan from borrowers. A similar phenomenon is also observed in term of project length. In particular, projects with more than $25 \mathrm{~km}$ road length receive a higher loan from borrowers.

Table 3. Group comparison by factors

By GDP per capital (Group $1 \geq 2000$ USD, Group $2<2000$ USD)

\begin{tabular}{|c|c|c|c|c|c|c|c|c|c|}
\hline & \multicolumn{2}{|c|}{ Levene's Test } & \multicolumn{7}{|c|}{ t-test for Equality of Means } \\
\hline & \multirow[t]{2}{*}{$\mathrm{F}$} & \multirow[t]{2}{*}{ Sig. } & \multirow[t]{2}{*}{$\mathrm{t}$} & \multirow[t]{2}{*}{ df } & \multirow[t]{2}{*}{$\begin{array}{l}\text { Sig. (2- } \\
\text { tailed) }\end{array}$} & \multirow[t]{2}{*}{$\begin{array}{c}\text { Mean } \\
\text { Difference }\end{array}$} & \multirow[t]{2}{*}{$\begin{array}{l}\text { Std. Error } \\
\text { Difference }\end{array}$} & \multicolumn{2}{|c|}{$\begin{array}{c}95 \% \text { Confidence } \\
\text { Interval of the } \\
\text { Difference }\end{array}$} \\
\hline & & & & & & & & Lower & Upper \\
\hline \multirow{2}{*}{$\begin{array}{l}\text { PC by Loan } \\
\text { (Mil.USD) }\end{array}$} & 4.33 & .04 & 2.31 & 46.00 & .03 & 50.72 & 21.91 & 6.61 & 94.83 \\
\hline & & & 2.16 & 24.33 & .04 & 50.72 & 23.52 & 2.21 & 99.23 \\
\hline \multicolumn{10}{|c|}{ By Project length (Group $1 \geq 25$ km, Group $2<25$ km) } \\
\hline & \multicolumn{2}{|c|}{ Levene's Test } & \multicolumn{7}{|c|}{ t-test for Equality of Means } \\
\hline & \multirow[t]{2}{*}{$\mathrm{F}$} & \multirow[t]{2}{*}{ Sig. } & \multirow[t]{2}{*}{$\mathrm{t}$} & \multirow[t]{2}{*}{ df } & \multirow[t]{2}{*}{$\begin{array}{l}\text { Sig. (2- } \\
\text { tailed) }\end{array}$} & \multirow[t]{2}{*}{$\begin{array}{c}\text { Mean } \\
\text { Difference }\end{array}$} & \multirow[t]{2}{*}{$\begin{array}{l}\text { Std. Error } \\
\text { Difference }\end{array}$} & \multicolumn{2}{|c|}{$\begin{array}{c}95 \% \text { Confidence } \\
\text { Interval of the } \\
\text { Difference }\end{array}$} \\
\hline & & & & & & & & Lower & Upper \\
\hline \multirow{2}{*}{$\begin{array}{l}\text { PC by Loan } \\
\text { (Mil.USD) }\end{array}$} & 3.53 & .07 & 2.18 & 46.00 & .03 & 50.82 & 23.30 & 3.92 & 97.72 \\
\hline & & & 2.99 & 36.71 & .00 & 50.82 & 16.98 & 16.41 & 85.23 \\
\hline
\end{tabular}




\section{Multilayer Perceptron Analyses}

A multilayer perceptron analysis has been conducted to examine the relationship between total construction time delay and its covariates. There are seven covariates considered for analysis including experiences of management units, experiences of investors, cost modified status, number of investors, site dispersion (i.e., number of site locations), number of provinces and involvement of new construction (i.e., a new road section is built). These factors are selected in a nature that they are factors those can be controlled in the project preparation phase and that they potentially affect the project schedule in the construction phase. In a belief that a longer construction schedule has a higher probability of delay due to a longer exposed time for uncertainty, the planned construction time is considered as an influenced factor. As results, with $90 \%$ of the cases for training and $10 \%$ of the cases for testing, the model showed a good predicting ability with a $2.8 \%$ of incorrect prediction. A summary of the model is presented Table 4; the network information is presented in Table 5; and the importance of covariates in predicting the dependent variable is presented in Figure 2.

Table 4. Model summary

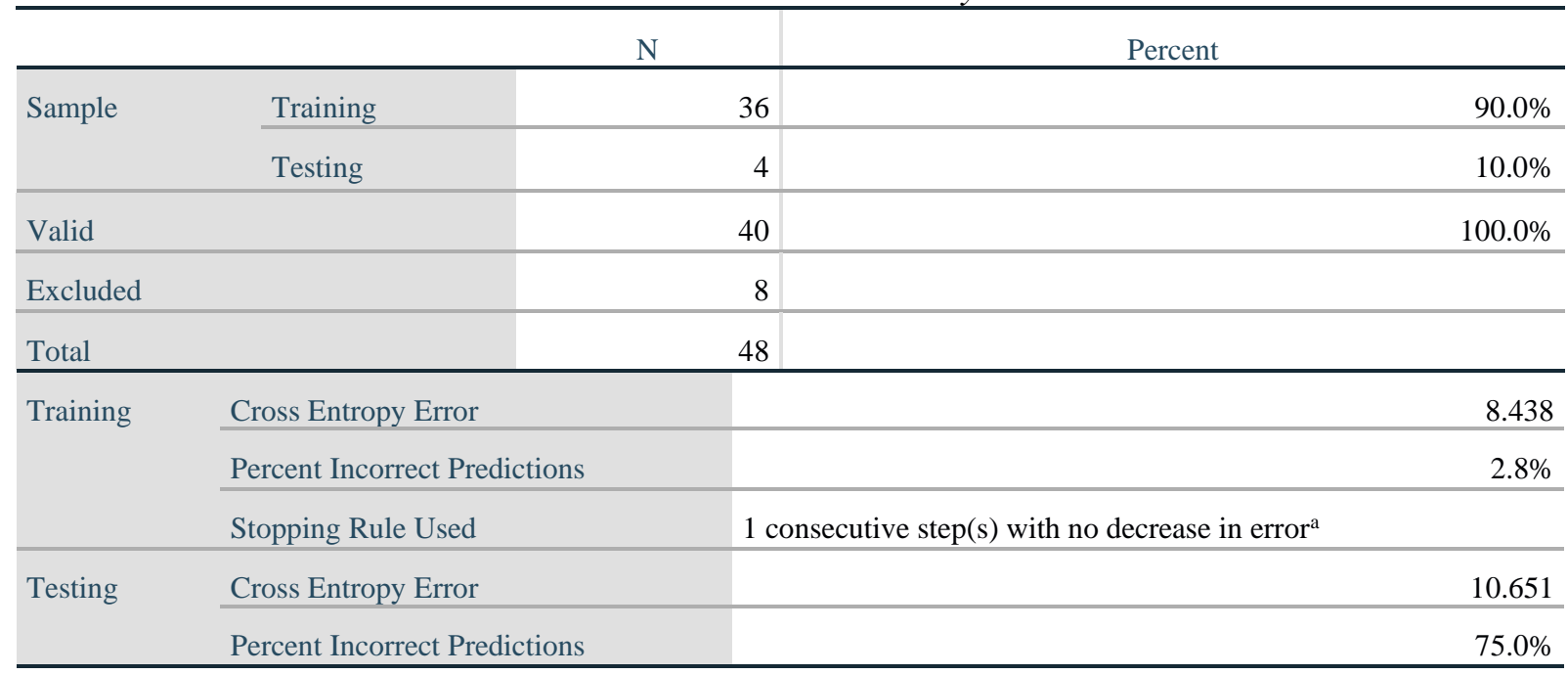

Dependent Variable: Delay; a. Error computations are based on the testing sample.

Table 5. Network information

\begin{tabular}{llll} 
Input Layer & Factors & 1 & Planned construction time in months \\
\cline { 2 - 3 } Covariates & 1 & Experiences of management unit \\
\cline { 2 - 3 } 2 & 3 & Experiences of investor \\
\hline & 4 & Modified status \\
\hline & 5 & No. of investors \\
\hline & 6 & Site dispersion \\
\hline Number of Units & & New construction involvement \\
\hline
\end{tabular}


Transport and Communications Science Journal, Vol. 70, Issue 3 (09/2019), 201-213

\begin{tabular}{llll} 
& Rescaling Method for Covariates & Standardized & 1 \\
\hline Hidden Layer(s) & Number of Hidden Layers & & 22 \\
\cline { 2 - 4 } & Number of Units in Hidden Layer 1 ${ }^{\mathrm{a}}$ & & Hyperbolic tangent \\
\hline Activation Function & Delay & 20 \\
\hline Output Layer & Dependent Variables & & \\
\hline & Number of Units & Softmax & Cross-entropy \\
\hline
\end{tabular}

a. Excluding the bias unit

As observed in Figure 2, number of investors, experiences of management unit and number of provinces are top three strongest factors affecting the total construction time of the investigated BOT road projects. The following-up strong factors are the involvement of new construction, number of site locations and experiences of investors. The weakest factors are status of cost modification and planned construction time.

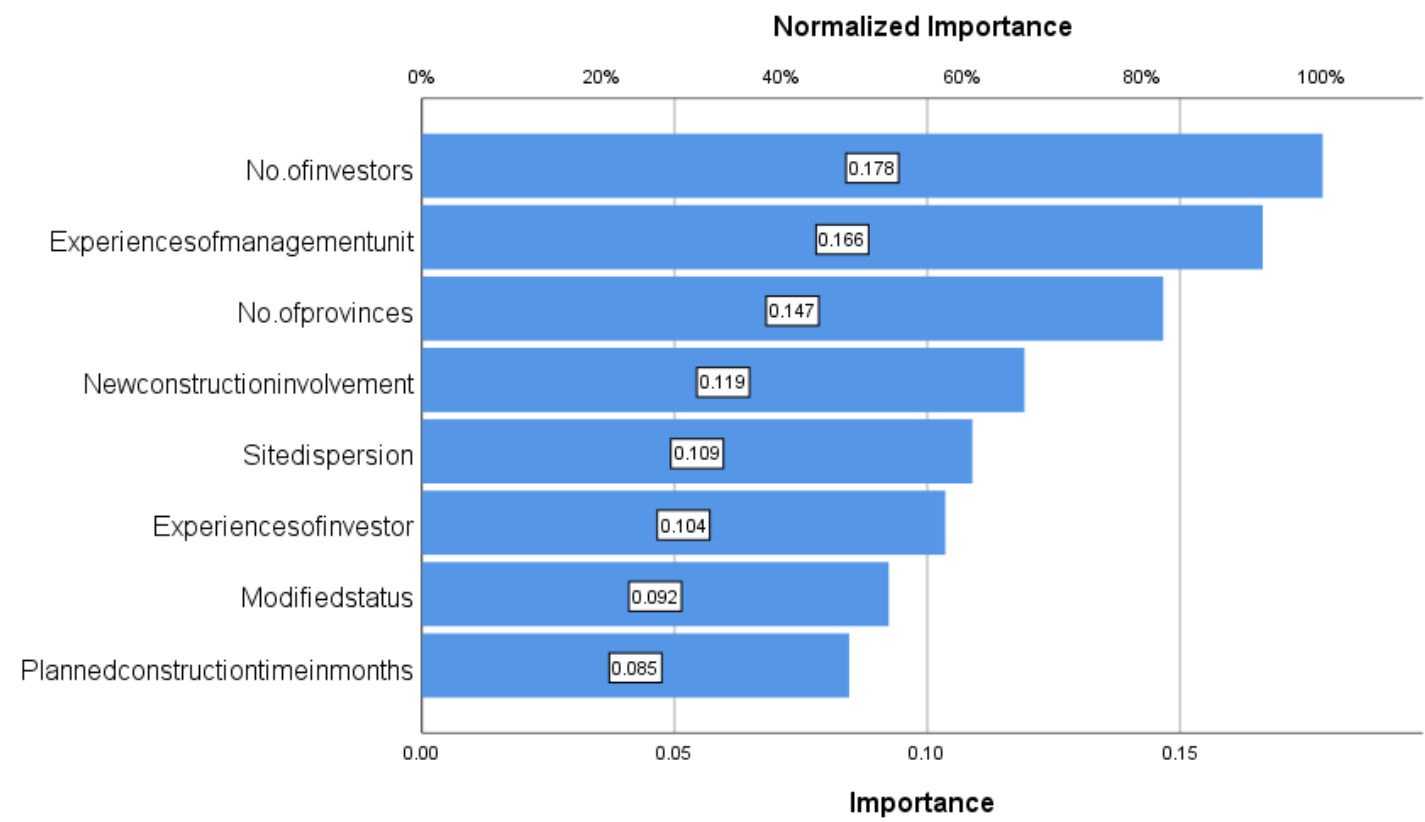

Figure 2. The importance of factors toward total construction time delay

\section{DISCUSSION}

Motivated by a belief that a good preparation can lead to a positive outcome, this study aims to examine impacts of various influenced factors of the project preparation phase on the total construction time of a BOT road project. Of the Vietnam context, acting as the first study focusing on identifying the risk of construction delay soon at the preparation phase, findings based on analyses of a large number of BOT road projects showed several important contributions to the practice of Vietnam.

First, it is found that more experienced investors tend to require a shorter project 
completion time. Other finding of this study, however, showed that a shorter planned construction time is associated with a longer construction time delay. This can be seen as a trade-off case where investors absolutely can set a long planned construction time to eliminate delays. It is however not their desire because they want to shorten the construction phase to proceed to the operation phase. This implies that a delay should be viewed in a trade-off scale and thus it is not always negative.

Second, GDP per capital should be a referred factor when making investment activities because the factor was found significantly positively associated with planned construction time and project length. In other words, project scope and construction time tend to be higher in a more developed location. Project managers should be aware of this for a better estimation of construction time which may consequently contribute to a change from a negative delay status to a positive delay status and vice versa.

Third, the statistically differences in loan amount between groups of GDP per capital and between groups of project length indicated that borrowers (e.g., commercial banks) have a more positive belief on a success of a project located in equal-or-more 2000 USD-GDP-percapital area as well as a success of an equal-or-longer-than- $25 \mathrm{~km}$ project. This is probably because travellers in more developed area may have a higher willingness to pay for road usage, thus contributing to a faster payback for BOT investors. Similarly, a larger project scope may indicate a more important project thus more users are going to use the project and this therefore guarantees the project success.

Fourth, results of multilayer perceptron model showed that the top three most influenced factors on total construction time delay are number of investors, experiences of management unit and number of provinces. With two out of top three factors are related to number of stakeholders, it is suggested that there is probably an issue of interest conflict among stakeholders [31] or a lack of a good coordination between stakeholders [18,32]. As such, future projects should focus on the problem of interest conflict as well as the coordination between stakeholders. Selecting a management unit with a good experience profile should also be important in reducing construction time delay.

\section{CONCLUSIONS}

Being the first study considering factors causing construction delay at the preparation phase, based on analyses of 48 BOT transport projects, this study has contributed to the literature several important findings, especially in Vietnam context. First, there are needs to consider a trade-off between total planned construction time and its delays, and a reasonable construction time estimation respectively to project scope and level of development of project area. And that, project capital is likely more secured by borrowers in equal-or-longer-than$25 \mathrm{~km}$ project length and/or equal-or-more 2000 USD in GDP per capital of project area. Notably, project managers should focus on issues of interest conflict, of coordination between stakeholders and experiences of management units because they are the top strongest 
Transport and Communications Science Journal, Vol. 70, Issue 3 (09/2019), 201-213

influenced factors of the preparation phase toward total completed construction time delay of the investigated projects. Future studies should address some limitations of this study including a limited number of investigated projects and the reliability of data provided by various interviewees.

\section{REFERENCES}

[1] X. Zhang, Critical success factors for public-private partnerships in infrastructure development, J. Constr. Eng. Manag., 131 (2005) 3-14.

[2] N. Agarchand, B. Laishram, Sustainable infrastructure development challenges through ppp procurement process: Indian perspective, Int. J. Manag., 10 (2017) 642-662. https://doi.org/10.1108/IJMPB-10-2016-0078

[3] R.L.K. Tiong, Comparative study of bot projects, J. Manag. Eng., 6 (1990) 107-122.

[4] R.L.K. Tiong, Competitive advantage of equity in bot tender, J. Constr. Eng. Manag., 121 (1995) 282-289. https://doi.org/10.1061/(ASCE)0733-9364(1995)121:3(282)

[5] K.C. Iyer, M. Sagheer, Hierarchical structuring of ppp risks using interpretative structural modeling, J. Constr. Eng. Manag., 136 (2010) 151-159.

[6] M. Sohail, D.A.C. Maunder, D.W.J. Miles, Managing public transport in developing countries: stakeholder perspectives in Dar es Salaam and Faisalabad, Int. J. Transp. Manag., 2 (2004) 149-160.

[7] X. Jin, G. Zhang, Modelling optimal risk allocation in PPP projects using artificial neural networks, Int. J. Proj. Manag., 29 (2011) 591-603.

[8] M.P. Abednego, S.O. Ogunlana, Good project governance for proper risk allocation in publicprivate partnerships in Indonesia, Int. J. Proj. Manag., 24 (2006) 622-634.

[9] E. Reeves, D. Palcic, D.Flannery, R.R. Geddes, The determinants of tendering periods for ppp procurement in the UK: an empirical analysis, Appl. Econ., 49 (2017) 1-12.

[10]F.M. Liou, C.P. Huang, Automated approach to negotiations of BOT contracts with the consideration of project risk, J. Constr. Eng. Manag., 134 (2008) 18-24.

[11] J. Yuan, A.Y. Zeng, M.J. Skibniewski, Q. Li, Selection of performance objectives and key performance indicators in public-private partnership projects to achieve value for money, Constr. Manag. Econ., 27 (2009) 253-270. https://doi.org/10.1080/01446190902748705

[12] M. Dunn-Cavelty, M. Suter, Public-private partnerships are no silver bullet: an expanded governance model for critical infrastructure protection, Int. J. Crit. Infrastruct. Prot., 2 (2009) 179-187.

[13] S.H. Bhuiyan, A crisis in governance: urban solid waste management in Bangladesh, Habitat International, 34 (2010) 125-133.

[14] O.M. Rouhani, H.O. Gao, R.R. Geddes, Policy lessons for regulating public-private partnership tolling schemes in urban environments, Transp. Policy, 41 (2015) 68-79.

[15] S.O.Babatunde, S. Perera, L. Zhou, C. Udeaja, Barriers to public private partnership projects in developing countries, Eng. Constr. Archit. Manag., 22 (2015) 669-691.

[16] K. Gidado, PFI implementation and evaluation model for developing economics: example of Nigeria. Proceeding of the 2010 International Conference on Engineering, Project, and Production Management, Pingtung, Taiwan, 14-15, 2010 available at: www.ppml.url.tw/EPPM/conference/2010 
Transport and Communications Science Journal, Vol. 70, Issue 3 (09/2019), 201-213

[17] A.P.C. Chan, P.T.I. Lam, D.W.M. Chan, E. Cheung, Y. Ke, Potential obstacles to successful implementation of public -private partnerships in Beijing and the Hong Kong special administrative region, Journal of Management in Engineering, 26 (2010) 30-40.

[18] E. Akampurira, D. Root, W. Shakantu, Stakeholder perceptions in the factors constraining the development and implementation of public private partnerships in the Ugandan electricity sector, Journal of Energy in Southern Africa, 20 (2009) 2-9.

[19] T. Quoc Cuong, Policy analysis for improving performance of PPP projects in Vietnam: A Case Study from BOT Phu My Bridge Project, Published master thesis, TU Delft, Delft University of Technology, 2010.

[20] H. T. T. Giang, Public-Private Partnerships: Development of road infrastructure in Vietnam, Published PhD thesis, University of Transport \& Communications and Transport, Vietnam, 2012.

[21] L. A. Tuan, Principal factors for Private Public Partnership (PPP) implementation in Vietnam: a mixed methods study, Published PhD thesis, University of Technology Sydney, 2016.

[22] The government inspectorate of Vietnam, Report on regulation implementation of BT, BOT contracts in transport section in Hanoi city, No. 1785/TB-TTCP, 2017.

[23] The government inspectorate of Vietnam, Report on regulation implementation of BT, BOT contracts in transport section in Ho Chi Minh city, No. 2242/TB-TTCP, 2017.

[24] The government of Vietnam, Report on PPP implementation results, No.25/BC-CP, 2019.

[25] Than Thanh Son, A study on risk allocation under PPP scheme for road infrastructure of Vietnam, Doctoral dissertation, University of Transport \& Communications, Vietnam, 2015.

[26] T. Liu, Y. Wang, S. Wilkinson, Identifying critical factors affecting the effectiveness and efficiency of tendering processes in Public-Private Partnerships (PPPs): A comparative analysis of Australia and China, International Journal of Project Management, 34 (2016) 701-716.

[27] B. Gültekin Çetiner, Murat Sari, Oğuz Borat. A Neural Network Based Traffic-Flow Prediction Model, Mathematical and Computational Applications, 15 (2010) 269-278.

[28] Concepcion Garrido, Rocio de Ona, Juan de Ona, Neural networks for analyzing service quality in public transportation, Expert Systems with Applications, 41 (2014) 6830-6838. https://doi.org/10.1016/j.eswa.2014.04.045

[29] V. Tu. Jack, Advantages and disadvantages of using artificial neural networks versus logistic regression for predicting medical outcomes, Journal of Clinical Epidemiology, 49 (1996) 1225-1231.

[30] J. S. R. Jang, C. T. Sun, E. Mizutani, Neuro-fuzzy and soft computing, Prentice Hall, USA, 1997.

[31] A. Akintoye, C. Hardcastle, M. Beck, E. Chinyio, D. Asenova, Achieving best value in private finance initiative project procurement, Construction Management and Economics, 21 (2003) 461-470. https://doi.org/10.1080/0144619032000087285

[32]R. Lamech, S. Kazim, What international investors look for when investing in developing countries: results from a survey of international investors in the power sector, Energy and Mineral Sector Board. Discussion Paper No. 6, The World Bank, Energy and Mining Sector Board, Washington, DC, 2003. 